\title{
Pola Komunitas Gua Di Sampung, Ponorogo
}

\section{Indah Asikin Nurani}

Keywords: pattern, function, cave, settlement, spatial, area

\section{How to Cite:}

Nurani, I. A. (2003). Pola Komunitas Gua Di Sampung, Ponorogo. Berkala Arkeologi, 23(2), 1-14. https://doi.org/10.30883/jba.v23i2.871

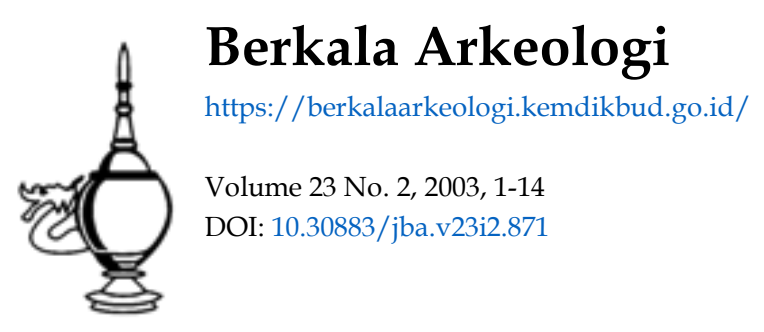

\section{(c) (1) (2)(2)}

This work is licensed under a Creative Commons Attribution-NonCommercial-ShareAlike 4.0 International License. 


\title{
POLA KOMUNITAS GUA DI SAMPUNG, PONOROGO
}

\author{
Indah Asikin Nurani
}

$\mathbf{P}$ endahuluan

Pola pemanfaatan lahan gua sebagai tempat tinggal atau tempat bermukim, menarik untuk dikaji lebih mendalam mengenai budaya manusia penghuni gua, terutama mengenai pola pemukiman yang diterapkan. Selama ini penelitian tentang permukiman masih dititikberatkan pada jangkauan penjajagan atau masih bersifat eksploratif. Dalam arkeologi, permukiman didefinisikan sebagai studi yang mengkhususkan atau memusatkan perhatiannya pada persebaran okupasi dan kegiatan manusia, serta hubungan-hubungan di dalam satuan-satuan ruang, dengan tujuan memahami sistem teknologi, sistem sosial, dan sistem ideologi dari masyarakat masa lalu (Mundarjito,1985). Selain itu, dalam kajian pemukiman juga dipelajari tentang pola yang terjadi dalam pengaturan tempat tinggal dan satuan-satuan komunitas yang ditata secara keruangan di muka bumi (Vogt, 1956). Dalam studi keruangan terdapat tiga tingkat ruang yaitu tingkat mikro (satu rumah tinggal), meso/semi mikro (beberapa rumah tinggal --desa--), dan tingkat makro (satu wilayah/kawasan) (Clarke, 1977). Berdasarkan pada pengertian tersebut, maka dalam mengkaji tentang pemanfaatan lahan gua sebagai tempat bermukim manusia, hal-hal penting yang perlu diperhatikan adalah kegiatan terkecil (skala mikro) dalam suatu gua, sebaran gua atau ceruk pada suatu wilayah, baik yang dimanfaatkan maupun tidak, selanjutnya dipelajari pola pemanfaatannya serta pola adaptasi yang dilakukan untuk mempertahankan hidupnya.

Penelitian mengenai kehidupan di gua-gua ataupun ceruk, di Indonesia selama ini telah banyak dilakukan, terutama penelitian yang dilakukan oleh peneliti asing. Berdasarkan penelitian mengenai budaya penghuni gua yang pernah dilakukan selama ini, menurut Simanjuntak (1996) dikelompokkan menjadi beberapa budaya yang meliputi budaya serpih bilah, budaya hoabinhian, budaya lukisan dinding gua, dan budaya Sampung. Semua budaya tersebut, menyebar dalam batas ruang yang berbedabeda. Budaya serpih bilah yang secara teknologis merupakan lanjutan dari teknologi paleolitik, persebarannya merata di seluruh kepulauan Indonesia dengan inovasi produk lokal yang khas pada masing-masing tempat. Mata panah dengan dasar cekung berkembang di Jawa Timur, lancipan bertangkai di Timor, mata panah bergerigi di Sulawesi Selatan, dan bilah memanjang dengan retus bersayap di sepanjang Sungai Nulbaki (Timor Barat). Budaya hoabinhian persebarannya lebih sempit daripada budaya serpih bilah, yaitu mendominasi daerah pesisir timur Sumatera utara dan Aceh, serta beberapa tempat di Jawa (Heekeren, 1972). Pola hidupnya cenderung bergantung pada subsistensi dengan eksploitasi sumberdaya aquatik dan non aquatik. Sementara itu, budaya lukisan dinding gua umumnya menempati Indonesia bagian 
timur. Budaya ini hingga sekarang belum pernah ditemukan di Jawa dan Sumatera. Sedangkan budaya Sampung mendominasi wilayah Jawa Timur dengan ciri utamanya berupa industri tulang, cangkang moluska, dan industri alat-alat serpih.

Penamaan budaya Sampung yang dikenal dengan industri tulang, berawal dari penelitian van Es pada tahun 1928 yang dilanjutkan oleh PV van Stein Callenfels di Gua Lawa. Sementara itu, penelitian pada gua/ceruk sekitar Gua Lawa kurang mendapatkan perhatian. Berdasarkan hal tersebut dan berangkat dari konsep permukiman sebagaimana diuraikan di atas, maka Balai Arkeologi Yogyakarta melakukan penelitian yang didasarkan pada studi arkeologi ruang pada himpunan gua kawasan Sampung. Dalam tulisan ini akan dijabarkan mengenai beberapa permasalahan yaitu : bagaimana pola pemanfaatan lahan masing-masing gua berkaitan dengan mikro settlement dan bagaimana pola komunitas yang berlangsung di kawasan Sampung?

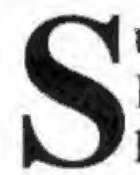

\section{umberdaya alam dan karakter budaya kawasan Sampung}

Kawasan Sampung, utamanya pada daerah perbukitan kapur memiliki kandungan gua atau ceruk sejumlah 16 buah. Secara geografis keletakan gua tersebut berada pada perbukitan kapur lereng tengah, di mana pada bagian lereng bawah terdapat Kali Areng. Gua/ceruk tersebut tidak seluruhnya memiliki indikasi hunian, hanya 6 buah gua yang memiliki indikasi hunian yaitu 5 buah gua (gua Lawa, gua Tutup, gua Padepokan, ceruk Layah, dan ceruk Ngalen) berada di bagian selatan, dan sebuah (gua Nggowos) berada di bagian utara perbukitan kapur Sampung. Indikasi hunian dida-sarkan pada hasil pengkaisan dan morfologi gua serta kondisi geografis sekitarnya.

Morfologi lahan Kecamatan Sampung terdiri atas 3 (tiga) bentuk lahan meliputi lahan dataran aluvial, perbukitan karst, dan dataran kaki gunung api (gunung Lawu). Dataran aluvial terletak pada bagian timur dan utara perbukitan karst yang dimanfaatkan sebagai areal permukiman dan persawahan. Bentuk lahan perbukitan karst merupakan areal perhutani dengan sebaran beberapa gua/ceruk. Areal perbukitan karst ini memanjang dari utara ke selatan, di mana pada bagian utara areal perbukitan sudah banyak yang ditambang. Sangat disayangkan, pada bagian ini terdapat sebuah gua (gua Ngowos) yang secara arkeologis sangat potensial, namun kondisinya sangat memprehatinkan (tingkat pengrusakan lanjut akibat penambangan sejak tahun 1923). Perbukitan karst ini terdiri atas lereng bawah yang merupakan Kali Areng, sedangkan lereng tengah dan lereng atas terdapat gua/ceruk. Sebagian besar gua/ceruk merupakan hasil rekahan dan pelarutan sehingga beberapa gua (gua Gedhe, gua Dlosor, Gua Nuton, dan gua Pertapan 2) terletak secara vertikal dan terjal pada punggung bukit. Keletakan gua tersebut secara aksesibilitas, menunjukkan tidak laiknya gua tersebut dihuni, selain sulit dijangkau, hasil pengkaisan juga tidak 


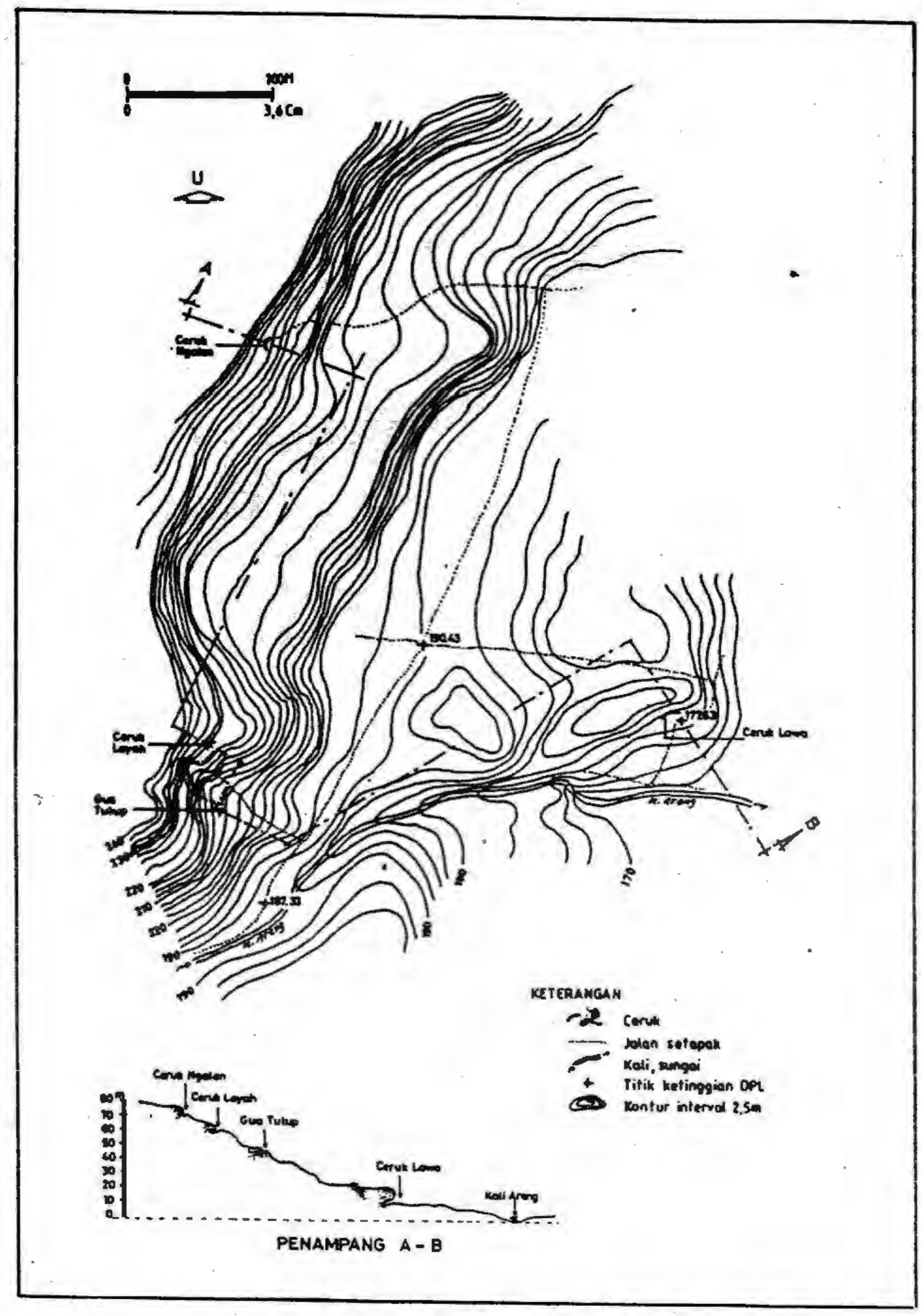

GAMBAR : SEBARAN SITUS GUA DI SAMPUNG

Berkala Arkeologi Th. XXIII (2) 
ditemukan indikasi hunian. Sedangkan bentuk lahan dataran kaki gunung api terletak pada bagian utara dari perbukitan kapur, saat ini areal tersebut dimanfaatkan sebagai persawahan dan perkebunan pinus.

Pemanfaatan sumberdaya alam dalam menyiasati pola hidup manusia saat itu tampak sangat berpengaruh. Hal tersebut didasarkan pada bentuk lahan yang bervariasi (perbukitan karst, aluvial, dan dataran gunung api) di mana masing-masing lahan tersebut ketersediaan makanan dan bahan baku untuk pembuatan alat mencukupi. Ini menunjukkan kawasan Sampung merupakan areal hunian yang baik.

Sejak tahun 2000 s.d 2002, Balai Arkeologi Yogyakarta melakukan penelitian di kawasan Sampung dengan melakukan survei dan ekskavasi. Ekskavasi dilakukan pada gua/ceruk sekitar Gua Lawa untuk mengetahui pola pemanfaatan masing-masing lahan gua. Gua/ceruk sekitar Gua Lawa yang telah dilakukan ekskavasi adalah Ceruk Layah, Ngalen, dan Sulur, berikut hasil ekskavasi yang telah dilakukan.

\section{Ceruk Layah}

Gua ini terletak di sebelah barat dari Gua Lawa berjarak sekitar $312.5 \mathrm{~m}$. yang merupakan sebuah ceruk berukuran dalam $5.40 \mathrm{~m}$, panjang $15.80 \mathrm{~m}$, dengan tinggi atap $3.70 \mathrm{~m}$, terletak pada satuan batuan batugamping kalkarinit berlapis dari Formasi Sampung. Gua ini merupakan hasil dari pengikisan atau erosi air permukaan setelah satuan batuan batugamping mengalami pengangkatan yaitu sekitar Kala Meosen Atas.

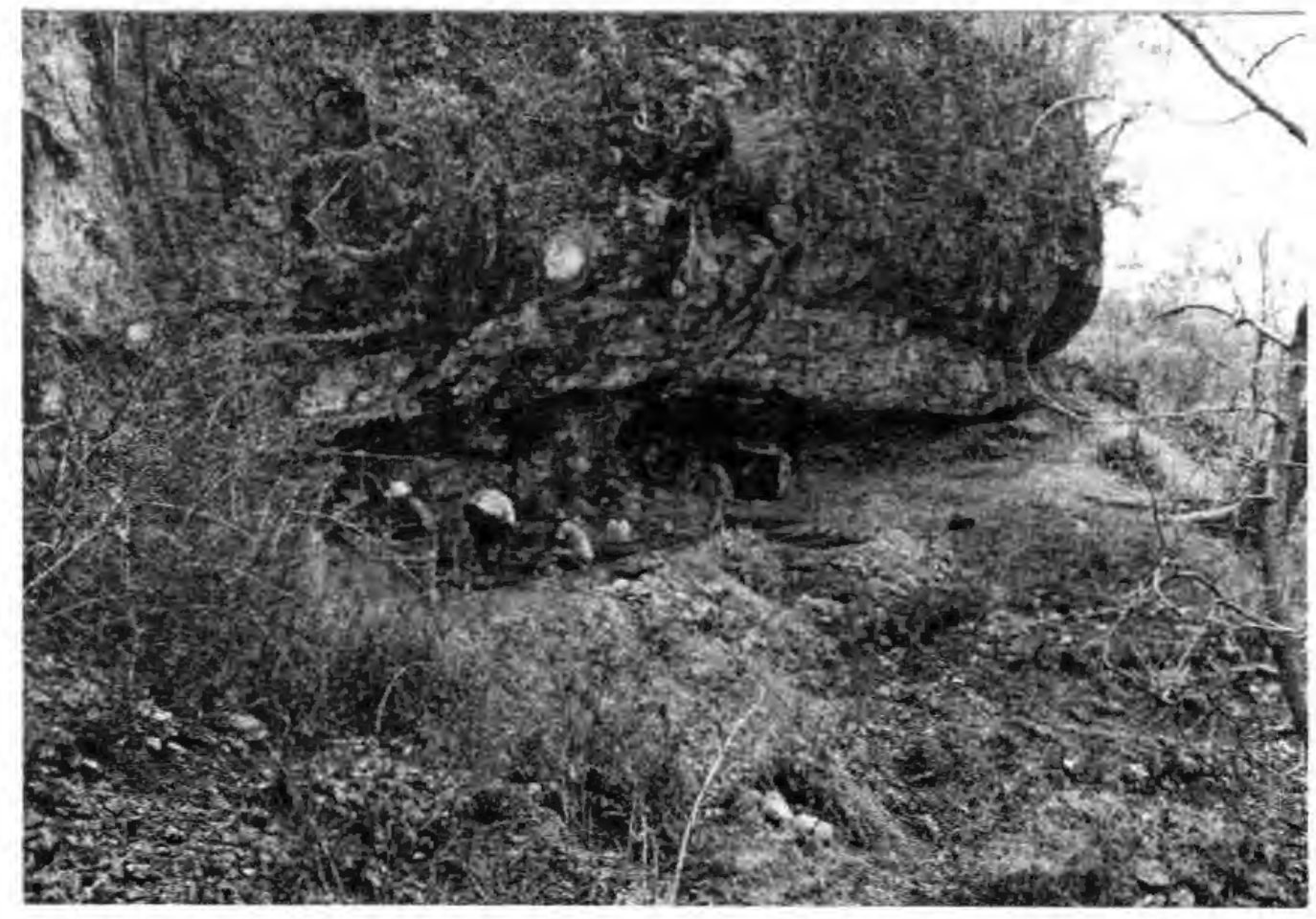


Pada dinding dan atap gua terlihat adanya rekahan dan pori-pori, namun dalam jumlah yang kecil. Hal ini disebabkan sinar matahari $80 \%$ dapat masuk ke dalam gua sehingga proses pelarutannya sangat kecil, sedangkan proses pelapukannya cukup tinggi. Endapan tanah pada permukaan gua berwarna coklat terang, kelembaban kecil, kekompakan rendah, dengan ketebalan tanah sekitar $60 \mathrm{~cm}$. Di sekitar gua banyak terdapat batugamping kersikan, rijang merah, rijang kuning berukuran berangkal sampai bongkah, baik masih insitu maupun fragmental.

Di bagian depan gua ini mengalir Kali Areng yang terdapat singkapan intrusi andesit juga sebagai kontak antara satuan batuan batugamping kalkarenit dengan batuan intrusi. Batuan yang terdapat di sekitar gua adalah andesit, batugamping kalkarinit karsikan, batu rijang merah, batu rijang kuning, batu rijang coklat. batu rijang hijau, kuarsa, dan kuarsit. Arah hadap gua ini ke tenggara $\left(\mathrm{N} 125^{\circ}\right)$.

Ekskavasi yang dilakukan di Ceruk Layah meliputi 12 (duabelas) kotak yaitu : kotak B-5, C-2, C-4, C-5, C-6, C-9, D-8, C-3, C-7, C-10, D-3, dan D-9. Secara stratigrafis, kedua belas kotak gali tersebut terdapat 4 (empat) lapisan tanah, di mana lapisan 4 merupakan lapisan bedrock satuan batugamping formasi sampung. Secara ringkas keempat lapisan tanah adalah sebagai berikut (Nurani, 2002).

Lapisan I merupakan top soil, warna coklat gelap, ukuran butir pasir halus, kekompakan kecil, kelembaban kecil, fragmen batuangamping berukuran kerikil, arang kayu berukuran $2-3 \mathrm{~mm}$, banyak terdapat akar halus dari tumbuhan, strukturnya masif, tekstur kasar. Temuan pada lapisan ini meliputi fragmen tembikar, fragmen tulang fragmen cangkang siput, dan artefak litik.

Lapisan 2 merupakan pasir lempungan, coklat keabu-abuan, berukuran butir pasir sangat halus, kekompakan sedang, kelembaban kecil, semen karbonatan, fragmen batugamping berukuran kerakal - kerikil, sebaran tembikar, sedikit arang kayu berukuran $5-10 \mathrm{~mm}$., struktur masif, tekstur halus, pemilahan sedang. Temuan lapisan ini : fragmen tembikar, fragmen tulang, fragmen cangkang siput, dan artefak litik.

Lapisan 3 merupakan endapan lempung pasiran, coklat terang, kekompakan sedang, kelembaban kecil, semen karbonatan, fragmen batugamping berukuran berangkal kerakal, struktur masif, tekstur kasar, pemilahan buruk. Temuan pada lapisan ini adalah artefak batu baik berupa alat serpih maupun serpihan alat.

Lapisan 4 merupakan lapisan bedrock satuan batuan batugamping Formasi Sampung. 
Frekuensi temuan hasil ekskavasi Ceruk Layah dapat dilihat pada grafik di bawah.

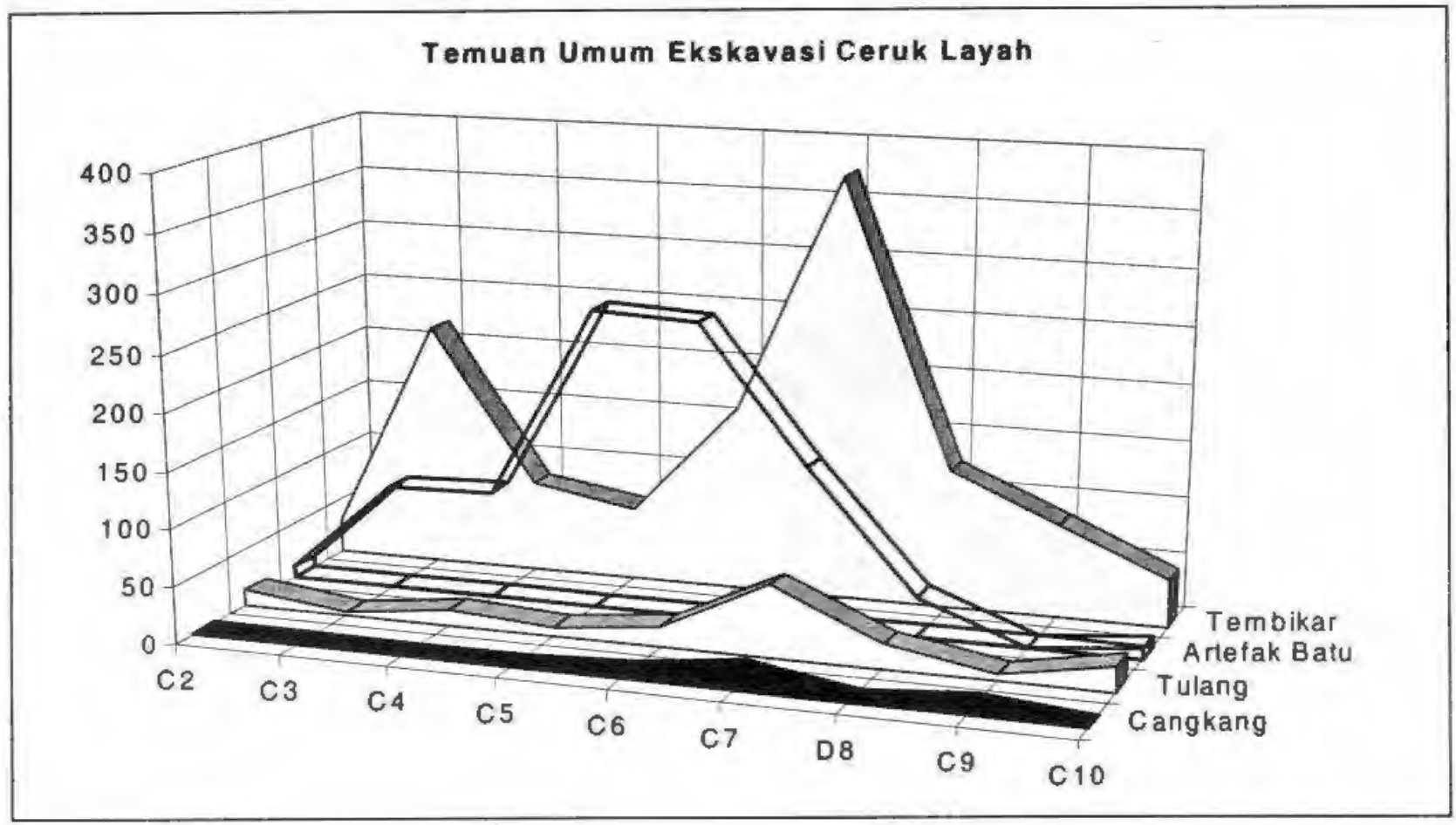

Grafik di atas menunjukkan bahwa temuan cenderung didominasi tembikar, setelah itu artefak litik. Apabila dilihat dari sebaran temuan kedua artefak tersebut menunjukkan pemanfaatan lahan yang berbeda antara temuan artefak litik dengan tembikar. Artefak litik lebih banyak memanfaatkan lahan bagian tengah, sedangkan tembikar cenderung melimpah di bagian kiri dan kanan ceruk. Kondisi ini jelas menunjukkan adanya pemanfaatan lahan yang berbeda untuk kedua aktivitas tersebut.

\section{Ceruk Ngalen}

Gua ini terletak di sebelah barat dari Gua Lawa berjarak sekitar $500 \mathrm{~m}$. Gua Ngalen adalah gua yang terdapat pada satuan batuan batugamping kalkarinit berlapis dari Formasi Sampung dan merupakan jenis gua ceruk dengan ukuran lebar (dalam) $4.3 \mathrm{~m}$, panjang $16 \mathrm{~m}$, dan tinggi $4.5 \mathrm{~m}$. Beberapa tempat terlihat adanya sementasi $\mathrm{CaCO}_{3}$ pada rekahan-rakahan dinding gua dan juga pada atap gua. Intensitas sinar matahari dapat masuk ke dalam gua $90 \%$ sehingga gua ini memiliki kelembaban yang kecil. Hal ini juga mengakibatkan tidak berkembangnya proses pembentukan stalagtit dan stalakmit, termasuk juga proses pelapukan batuan cukup intensif yang menghasilkan fragmen-fragmen batugamping yang berukuran butir kerikil-kerakal. Pada beberapa bagian terlihat adanya batugamping yang mengalami silificate menjadi batugamping kersikan. Kondisi lantai tertutup material tanah sekitar $20 \mathrm{~cm}$ dengan arah kemiringan lantai $\mathrm{N} 255^{\circ} / \mathrm{E} 4^{\circ}$, tanah permukaan berwarna coklat keputih-putihan, kelembaban rendah, berukuran pasir halus, dan kekompakannya sangat rendah. Tampaknya tanah 
permukaan sekarang telah mengalami penurunan sekitar $30 \mathrm{~cm}$. Hal ini terlihat pada dinding gua yang masih meninggalkan sisa-sisa endapan tanahnya (paleolevel soil of cave). Di sekitar gua banyak terdapat rijang merah, rijang coklat, dan rijang kuning berukuran bongkah, baik yang masih insitu maupun yang berupa fragmen lepas. Gua ini merupakan gua hasil dari pengikisan atau erosi air permukaan setelah satuan batuan batugamping mengalami pengangkatan yaitu sekitar Kala Meosen Atas. Arah hadap gua ke timurlaut $\left(\mathrm{N}^{\circ} 0^{\circ}\right)$, yaitu ke arah lembah/dataran yang ditanami pohon jati.

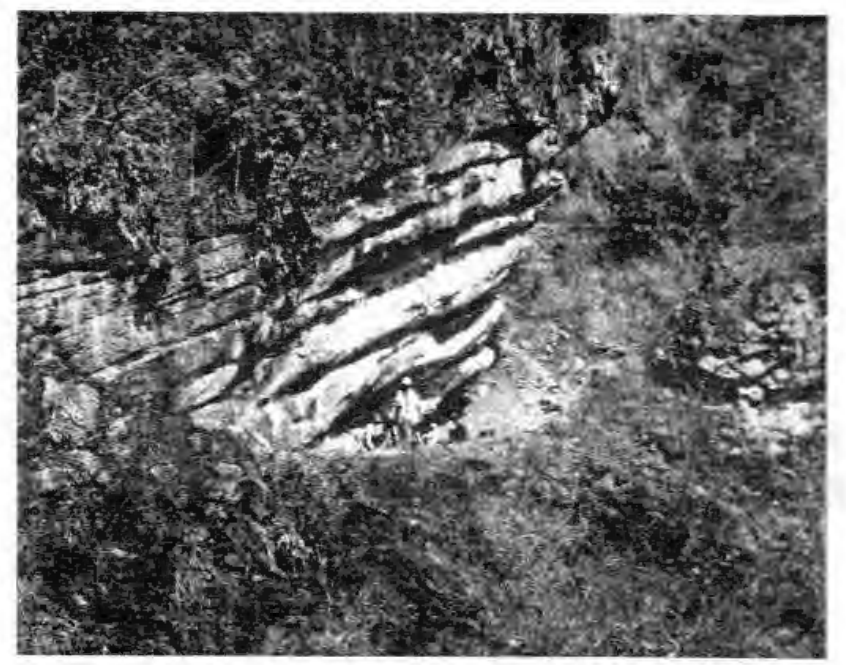

Ekskavasi yang dilakukan di Ceruk Ngalen dengan membuka tiga kotak yaitu A3, A5, dan B1. Sebagaimana pada Ceruk Layah, stratigrafis tanah pada ceruk ini terdiri atas empat lapisan, di mana pada lapisan 4 merupakan lapisan bedrock yaitu satuan batuan Formasi Sampung. Adapun hasil ekskavasi pada ketiga kotak gali ini adalah sebagai berikut (Nurani, 2002).

Lapisan 1 merupakan lapisan top soil. Temuan lapisan pertama ini untuk kotak A3 berupa fragmen tembikar sejumlah 11 buah, untuk kotak B-1 berupa $10 \mathrm{bh}$ fragmen batu (baik sebagai bahan baku, limbah ataupun alat); sebuah fragmen cangkang siput; sebuah mata uang; 18 bh fragmen tembikar; dan 2 bh fragmen tulang.

Lapisan kedua merupakan endapan pasir lempungan, warna coklat keabu-abuan, ukuran butir pasir halus. Temuan pada lapisan ini untuk kotak A3 meliputi fragmen tembikar 105 buah dan artefak batu 11 buah, kotak A- 5 berupa sebuah alat tulang; 15 bh fragmen batu; 2 bh fragmen cangkang siput; 2 bh fragmen kulit kemiri; 37 bh fragmen tembikar; dan 4 bh fragmen tulang; sedangkan kotak B-1 berupa sebuah alat tulang; 44 bh fragmen batu; 3 bh fragmen tembikar; dan 8 bh fragmen tulang.

Lapisan ketiga merupakan endapan lempung pasiran, warna coklat keputih-putihan, ukuran butir lempung. Temuan pada lapisan ini pada masing-masing kotak berhasil ditemukan sebagai berikut: kotak A-3 meliputi fragmen tembikar 110 buah, artefak batu 7 buah, fragmen tulang 2 bh, dan fragmen cangkang siput 5 bh; kotak A- 5 berupa sebuah alat tulang, 4 bh fragmen batu; sebuah fragmen cangkang siput; 6 bh fragmen kulit kemiri; sebuah mata uang; 71 bh fragmen tembikar; dan 15 bh fragmen tulang, sedangkan kotak B-1 berupa 15 bh fragmen batu dan 3 bh fragmen tulang. 
Secara keseluruhan frekuensi temuan ketiga kotak gali dapat dilihat pada grafik berikut.

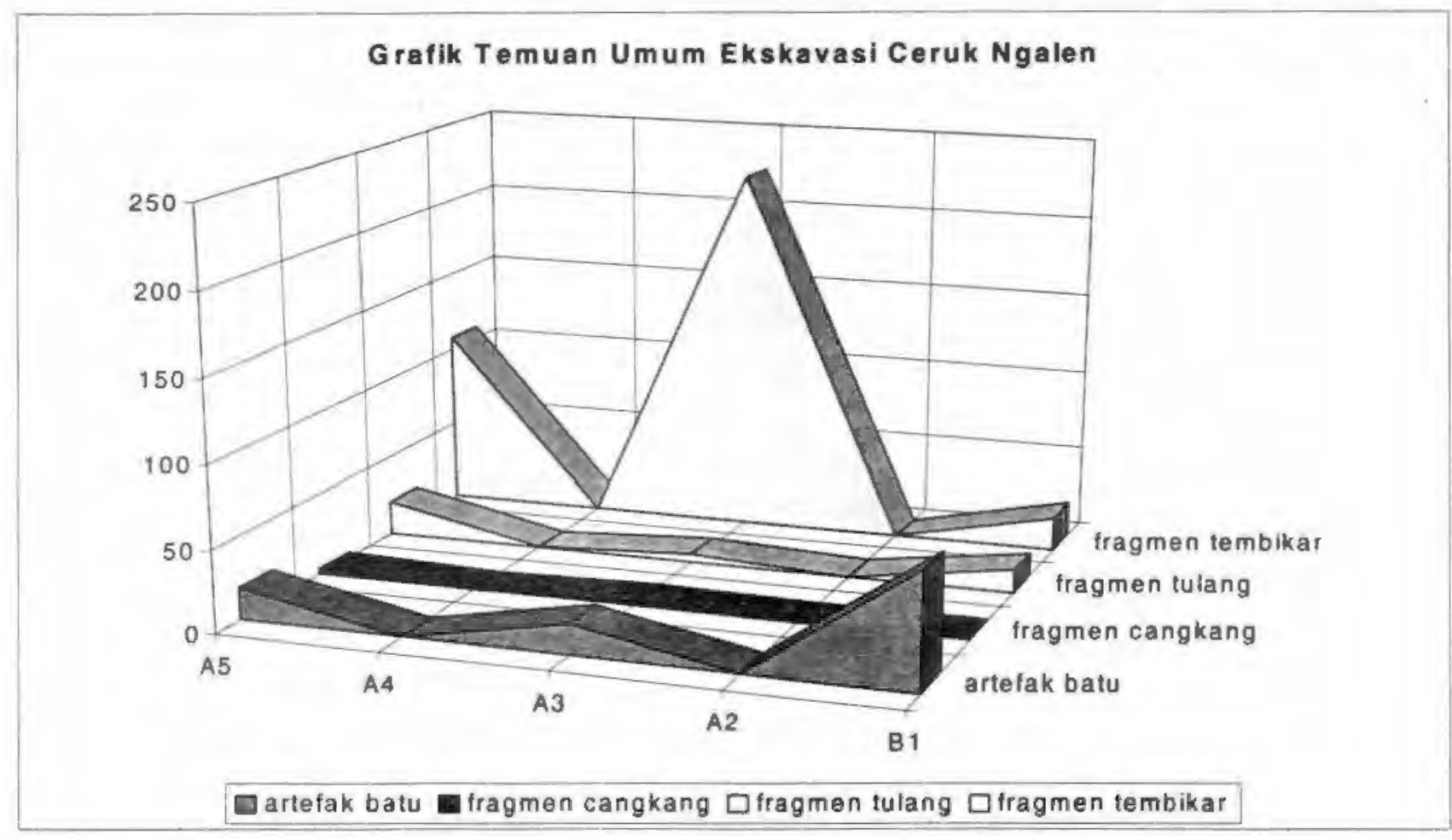

\section{Ceruk Sulur}

Gua ini terletak di sebelah tenggara Gua Ngalen berjarak sekitar $95 \mathrm{~m}$. Gua Sulur terdapat pada satuan batuan batugamping kalkarinit berlapis yang merupakan anggota penyusun Formasi Sampung dan merupakan jenis gua ceruk. Gua ini terbentuk akibat dari hasil pengikisan atau erosi air permukaan setelah satuan batuan batugamping mengalami pengangkatan, dimana gua terletak pada sea level yaitu sekitar Kala Meosen Atas. Beberapa tempat terlihat adanya sementasi larutan $\mathrm{CaCO}_{3}$ pada rekahan-rakahan dinding gua dan juga pada atap gua. Sedangkan pada dinding dan atap gua banyak terdapat pori-pori dan rekahan-rekahan yang tidak tersementasi sehingga batugamping pada atap mengalami pelapukan dan siap runtuh. Intensitas sinar matahari dapat masuk ke dalam gua $90 \%$, sehingga gua ini memiliki kelembaban yang kecil. Hal ini mengakibatkan tidak berkembangnya proses pembentukan stalagtit dan stalakmit, termasuk juga proses pelapukan batuan cukup intensif yang menghasilkan fragmen-fragmen batugamping yang berukuran butir kerikil-kerakal. Pada bagian depan gua terdapat fragmen batugamping yang berukuran bongkah dan merupakan hasil runtuhan dari atap gua. Hal ini dapat dilihat dari orientasi bentuk fragmen yang sama dengan orientasi bekas pada langit-langit gua tersebut. Keletakan gua ini pada lereng sebuah bukit karst dengan kemiringan lereng $45^{\circ}$ dan menghadap ke suatu lembah sehingga secara geomorfologi terletak pada bentang alam yang bergelombang kuat. Morfologi permukaan lantai gua bergelombang lemah dengan 
kemiringan $10^{\circ}$ dengan arah relatif ke bagian timur. Lantai ini disusun oleh material tanah berwarna coklat keputih-putihan, berukuran butir pasir sangat halus - sedang, agak kompak, ketebalan sekitar $30 \mathrm{~cm}$ di bagian timur dan $50 \mathrm{~cm}$ di bagian barat, sedangkan kelembabannya sangat rendah. Material tanah ini diperkirakan dari luar gua yang masuk oleh media air maupun angin, baik melalui pori-pori batu gamping, kekar-kekar dan pintu gua. Namun saat ini terlihat adanya transportasi tanah dari dalam gua ke luar gua sehingga permukaan sekarang lebih rendah $30 \mathrm{~cm}$ dari permukaan pada saat gua itu terbentuk. Jadi pada gua ini proses erosional material penyusun lantai gua cukup intensif. Batuan yang ada di sekitar gua berupa fragmen kalsit, material batugamping kersikan, rijang merah, rijang kuning, dan rijang coklat yang berukuran berangkal-bongkah, baik yang masih insitu maupun material lepas.

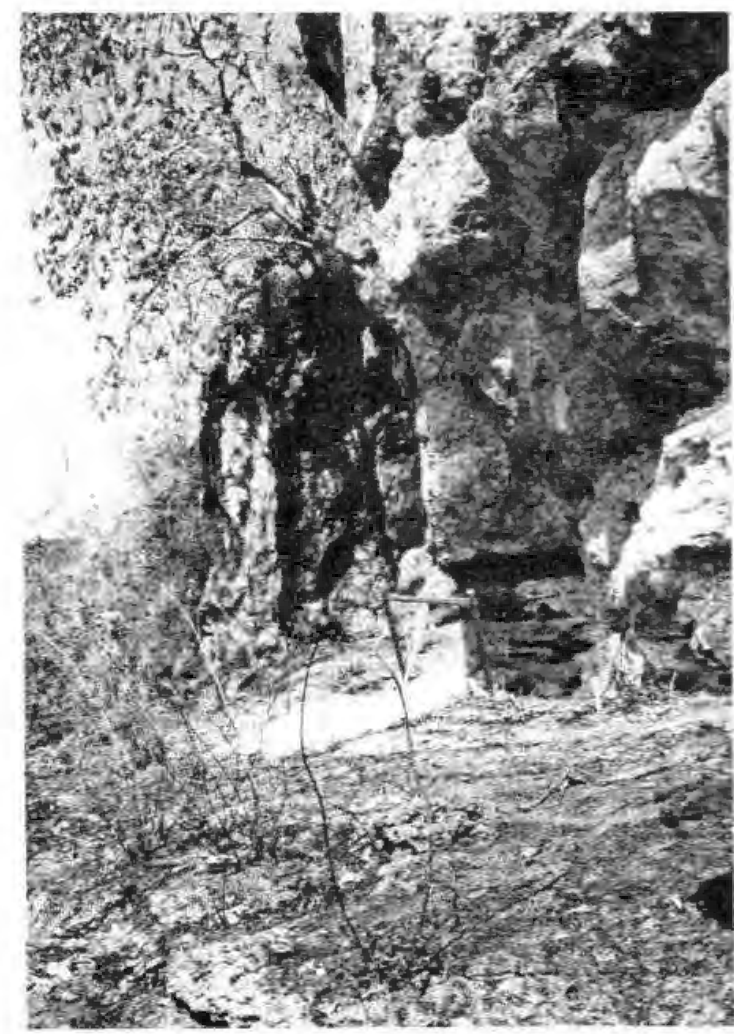

Ekskavasi yang dilakukan di Ceruk Sulur sebagai pembanding dari kedua ceruk yang telah diekskavasi. Hal tersebut penting dilakukan mengingat kedua ceruk yang telah diekskavasi cenderung didominasi temuan artefak batu pada lapisan akhir sedangkan lapisan awal didominasi temuan tembikar. Kenyataan tersebut menarik untuk diketahui apakah seluruh ceruk sekitar Gua Lawa pada perbukitan Angel, Sampung ini dimanfaatkan untuk aktivitas pembuatan alat batu.

Sebagaimana diketahui kedua ceruk yang telah diekskavasi menunjukkan minimnya temuan fauna baik aquatik maupun non aquatik. Konteks kehidupan prasejarah justru didominasi dengan temuan artefak batu. Berdasarkan hal tersebut muncul pertanyaan apakah ceruk-ceruk sekitar Gua Lawa hanya dimanfaatkan untuk aktivitas pembuatan alat sedangkan pengolahan daging buruan dilakukan di Gua Lawa, di mana gua tersebut cukup banyak ditemukan sisasisa makanan baik fauna aquatik maupun non aquatik?.

Pembukaan kotak gali pada ceruk ini dimaksudkan untuk mengetahui pemanfaatan lahan yang tersedia apakah dimanfaatkan sebagai aktivitas atau tidak. Karenanya dibuka sebuah lubang uji dengan nama LU-1. Dalam ekskavasi ini berhasil ditemukan 2 bh alat tulang; 199 bh fragmen batu baik berupa bahan baku, limbah maupun alat; 2 bh fragmen cangkang siput; 295 bh fragmen tembikar; dan 12 bh fragmen tulang. 


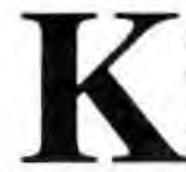

\section{arakter Gua Lawa}

Temuan arkeologis pada Gua Lawa (Heekeren, 1972) meliputi berbagai lapisan budaya yang menunjukkan berbagai fase meliputi masa sejarah (lapisan atas) dan masa prasejarah (lapisan bawah).

Lapisan teratas merupakan lapisan masa sejarah. Dalam lapisan ini ditemukan fragmen tembikar baru, kaca, fragmen keramik Cina, alat-alat logam dari besi, perunggu, dan tembaga. Di anatara fragmen tembikar dan kaca terdapat sembilan buah sudip tulang. Alat-alat ini diperkirakan tidak in situ.

Lapisan berikutnya merupakan lapisan neolitik yang didasarkan dengan temuan beliung persegi. Temuan beliung persegi ditemukan bersama dengan fragmen tembikar, batu giling, alat logam, dan beberapa buah sudip dari tulang.

Di bawah lapisan neolitik terdapat lapisan yang ditandai dengan banyaknya temuan berupa alat tulang dan tanduk. Bagian terbesar alat tulang berupa sudip baik tebal maupun tipis serta pipih, sedangkan alat lainnya berupa lancipan, serta matapanah atau mata tombak. Beberapa alat tanduk yang didapatkan menyerupai belati atau pencungkil. Alat tanduk ini biasanya dibuat dari tanduk rusa atau kijang. Alat ini dibentuk membulat dan berujung meruncing dengan cara menggosok. Alat tulang berupa sudip tebal kebanyakan berada di bagian atas lapisan ini sedangkan sudip tipis berada di bagian bawah. Temuan lainnya adalah berupa perhiasan dari cangkang moluska. Perhiasan ini ditemukan dekat penguburan yang merupakan rangka seorang anak.

Lapisan budaya di bawah alat tulang dan tanduk ditandai dengan temuan matapanah bersayap dari batu, tetapi kedua lapisan ini sangat sulit ditentukan batasnya. Sejumlah sudip tulang masih ditemukan di antara matapana-matapanah tersebut. Selain itu temuan lainnya adalah sejumlah batu giling serta fragmen tembikar.

Sementara itu pada bagian lain banyak ditemukan artefak litik berupa serpih bilah yang diretus dan tidak diretus. Temuan menarik adalah berupa serut yang dibuat dari kerakal, pada bagian lateralnya masih terdapat korteks, tajamannya berbentuk melengkung dan menunjukkan adanya pengerjaan sekunder. Selain temuan artefak, ditemukan pula rangka manusia dalam posisi kaki terlipat dan tangan ditekuk di depan tubuhnya. Di atas rangka biasanya terdapat lempengan batu yang menindihnya. Kebanyakan temuan berada di dekat dinding gua, namun orientasinya tidak jelas. Tidak semua temuan rangka dalam keadaan lengkap, bahkan hampir semua dalam keadaan rapuh.

Di samping temuan artefak dan rangka manusia, hampir di seluruh lapisan ditemukan sisa-sisa makanan baik berupa sisa tanaman maupun binatang. Sisa-sisa tanaman yang 
ditemukan di beberapa tempat berupa kulit dari buah tertentu yang sulit diidentifikasi. Sementara itu temuan sisa-sisa binatang cukup banyak tersebar di seluruh lapisan. Di antara sisa-sisa binatang yang berhasil diidentifikasi terdapat tulang ikan, cangkang moluska baik gastropoda maupun pelecypoda, tulang primata, binatang berkuku, carnivora, rodensia, dan herbivora.

Berdasarkan berbagai temuan baik artefak, rangka manusia, maupun sisa-sisa makanan, menunjukkan bahwa Gua Lawa memiliki jejak-jejak seluruh aktivitas secara kompleks. Dapat disimpulkan berda-sarkan temuan pada posisi lapisan tanah (vertikal atau waktu) dan sebaran secara horisontal menunjukkan Gua Lawa dimanfaatkan multifungsi. Pemanfaatan multifungsi tersebut didasarkan pada jenis-jenis temuan sebagai jejak-jejak aktivitas yang pernah berlangsung. Secara keseluruhan aktivitas yang berlangsung pada Gua Lawa adalah aktivitas perbengkelan, pengolahan makanan, dan penguburan.

Berkaitan dengan kenyataan tersebut dan melihat potensi budaya yang terdapat pada ceruk-ceruk sekitar Gua Lawa, dapat disimpulkan bahwa Gua Lawa merupakan gua induk atau pusat aktivitas masyarakat komunitas gua di Sampung. Lebih lanjut dapat dibandingkan uraian berikut mengenai potensi budaya yang terdapat pada ceruk-ceruk sekitar Gua Lawa.

$\mathbf{P}$ eranan ceruk-ceruk sekitar Gua Lawa dalam aktivitas komunitas Potensi budaya yang terjadi pada ceruk-ceruk sekitar Gua Lawa sangat berbeda dengan Gua Lawa. Sebagaimana telah dijelaskan di atas, potensi budaya yang terdapat pada Gua Lawa sangat kompleks dan beragam. Dari segi vertikal (waktu) pemanfaatan Gua Lawa difungsikan dalam jangka waktu yang lama (sejak mesolitik sampai masa sejarah), sedangkan dari segi horisontal (ruang) pemanfaatan lahan gua menunjukkan beragamnya aktivitas yang pernah berlangsung. Kondisi tersebut berbeda dengan potensi budaya yang berlangsung pada ceruk-ceruk sekitar Gua Lawa, seperti Ceruk Layah, Ceruk Ngalen, dan Ceruk Sulur.

Sebagaimana telah dijelaskan pada bagian sebelum ini, ceruk-ceruk sekitar Gua Lawa lebih didominasi oleh temuan artefak litik (lapisan bawah) dan tembikar (lapisan atas), sementara temuan lainnya berupa sisa makanan baik fauna marin maupun darat (ekofak) sangat minim. Hal tersebut menunjukkan aktivitas yang pernah berlangsung pada ceruk-ceruk sekitar Gua Lawa adalah aktivitas pembuatan dan pemakaian alat litik. Sedangkan berdasarkan minimnya sisa-sisa makanan menunjukkan bahwa pengolahan makanan tidak dilakukan pada ceruk-ceruk tersebut. 
Berdasarkan uraian tersebut di atas mengenai pemanfaatan lahan masing-masing gua --dalam hal ini Gua Lawa, Ceruk Layah dan Ceruk Ngalen-- dapat dibuat skema skala mikro pemanfaatan gua yang ada pada kelompok gua di Sampung, sebagai berikut :

\section{PEMANFAATAN LAHAN GUA (SKALA MIKRO)}

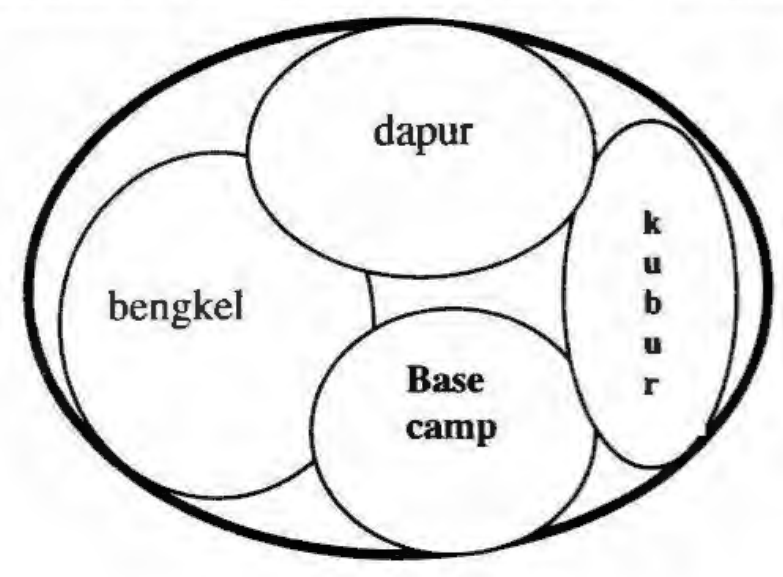

GUA LAWA
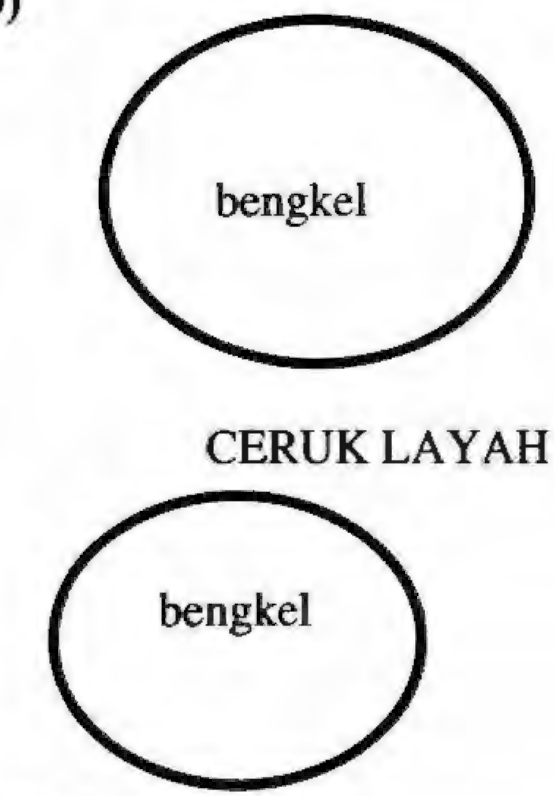

CERUK NGALEN

Perbedaan aktivitas antara Gua Lawa dengan ceruk-ceruk sekitarnya didukung pula dengan keletakan morfologi lahan, di mana keletakan ceruk-ceruk sekitar Gua Lawa ini berada pada puncak-puncak bukit menghadap suatu bentangan lembah seluruh wilayah Sampung. Sementara itu sebagaimana telah diuraikan pada bab B perbukitan karst ini menyimpan potensi jenis batuan dengan silikaan cukup baik sebagai bahan baku pembuatan alat batu. Bahan baku alat ini tersebar luas baik masih insitu maupun berupa fragmen di sekitar perbukitan. Kondisi tersebut mempermudah pencarian sumber bahan baku untuk peralatan di mana pada puncaknya terdapat ceruk-ceruk yang dapat dimanfaatkan untuk berlindung.

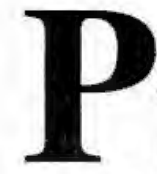

enutup

Sebagaimana telah dijelaskan di depan, masing-masing gua/ceruk, Layah, Ceruk Ngalen, dan Ceruk Sulur menunjukkan perbedaan yang menyolok. Tampaknya Gua Lawa pada komunitas ini dimanfaatkan sebagai gua induk, di mana seluruh aktivitas komunitas berlangsung. Sementara itu Ceruk Layah, Ceruk Ngalen, dan Ceruk Sulur dimanfaatkan untuk aktivitas pendukung. Hal tersebut didasarkan pada perbandingan hasil ekskavasi antara Gua Lawa dengan ceruk-ceruk sekitarnya. Temuan artefak, ekofak dan fitur pada Gua Lawa lebih bervariasi baik kualitas maupun kuantitasnya dibanding ceruk-ceruk sekitarnya yang temuannya cenderung 
homogen berupa artefak litik. Selain itu, berdasarkan temuan artefak pada Ceruk Layah menunjukkan adanya perkembangan pemanfaatan ceruk. Pada awalnya (lapisan bawah) Ceruk Layah dimanfaatkan sebagai perbengkelan alat batu, selanjutnya pada masa kemudian (lapisan atas) didominasi temuan tembikar. Sementara temuan ekofak pada ceruk-ceruk sekitar Gua Lawa cenderung minim. Hal tersebut dapat disimpulkan bahwa pola komunitas gua di Sampung terdiri atas gua induk dengan kompleksitas budaya yang berlangsung dan gua/ceruk pendukung yang dimanfaatkan untuk aktivitas sekunder.

Apabila dugaan pemanfaatan lahan masing-masing gua pada kawasan Sampung tersebut benar, maka dapat diilustrasikan pola komunitas yang berlangsung pada daerah Sampung merupakan pola komunitas gua yang terdiri atas gua induk dengan pemanfaatan gua secara multi fungsi sebagai aktivitas induk dan kompleks (Gua Lawa) yang dikelilingi oleh gua atau ceruk yang digunakan sebagai aktivitas pendukung. Secara lebih jelas dapat digambarkan pola komunitas gua kawasan Sampung yang pernah berlangsung sebagaimana terlihat pada skema berikut.

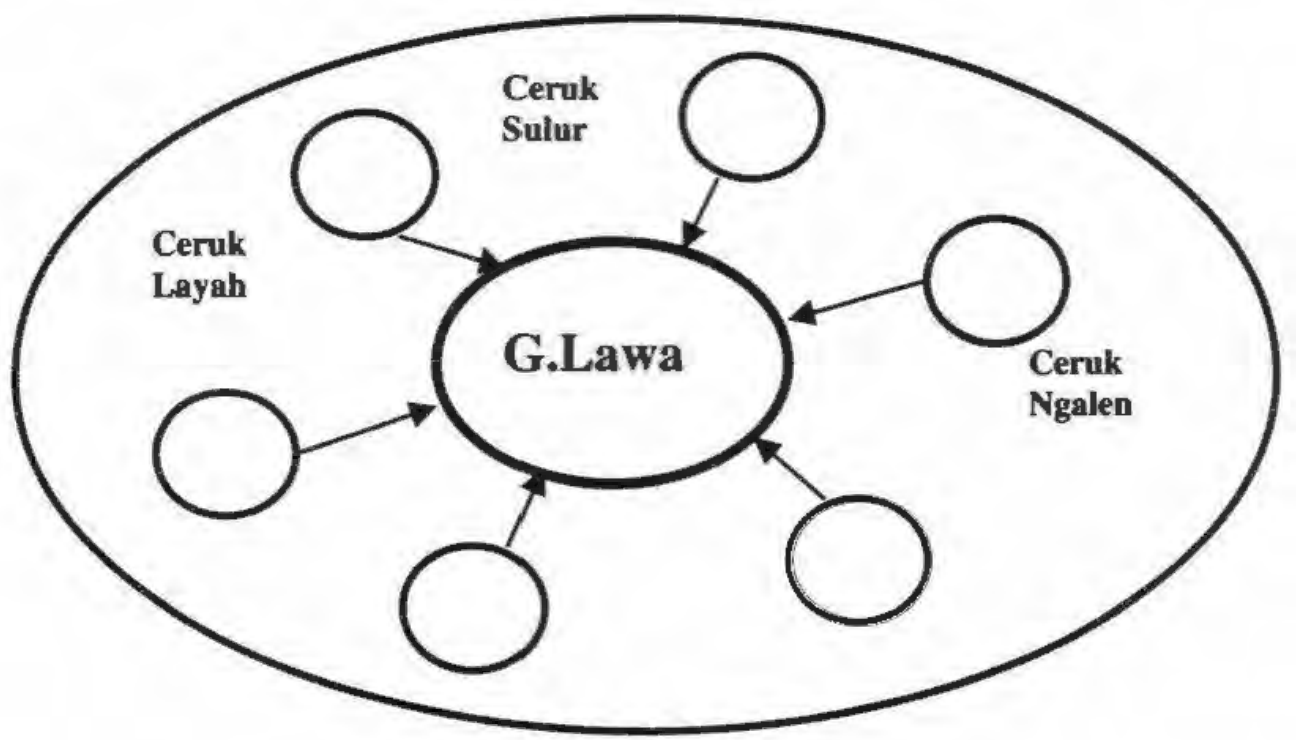




\section{KEPUSTAKAAN}

Clarke, 1977. Spatial Information in Archaeology, in Spatial Archaeology. London : Academic Press, pp. 1-23

Heekeren, HR van., 1972, The Stone Age of Indonesia, Verhandelingen KITL V, XXI, 's-Gravenhage.

Mundardjito, 1985. Manfaat Studi Pemukiman Bagi Disiplin Ilmu Arkeologi. Diskusi Ilmiah Arkeologi VI. Tk 2 Jakarta : Ikatan Ahli Arkeologi Indonesia Komisariat Daerah DKI Jakarta dan Jawa Barat.

Nurani, Indah Asikin, 1998, LPA Pola Pemanfaatan Lahan Gua-gua Kabupaten Ponorogo, Yogyakarta: Balai Arkeologi. Belum diterbitkan

Simanjuntak, Harry Truman, 1996, Akhir Plestosen dan Awal Holosen di Nusantara (Bahasan Tentang Karakter dan Kronologi Budaya), PIA VII, Cipanas, Jawa Barat, belum diterbitkan.

Tanudirjo, Daud Aris, 1985. Budaya Sampung sebagai Budaya Transisi Masa Berburu dan Mengumpulkan Tingkat Lanjut ke Masa Bercocoktanam. Skripsi, Jurusan Arkeologi Fakultas Sastra, Universitas Gadjah Mada.

Vogt, E.Z. 1956. An Apprasial of 'Prehistoric Settlement Patterns' in the New World, in Prehistoric Settlement Patterns in the New World. Viking Fund Publication in Anthropology. 